\title{
Technology Acceptance Model (TAM) Untuk Menganalisis Penerimaan Pengguna Terhadap Penggunaan Aplikasi Belanja Online XYZ
}

\author{
Andre Mayjeksen*1, Desi Pibriana ${ }^{2}$ \\ 1,2Program Studi Sistem Informasi, STMIK Global Informatika MDP; \\ Jl. Rajawali No. 14 Palembang, 30113, Telp (0711) 376400 \\ e-mail:*11caadajh@mhs.mdp.ac.id, ${ }^{2}$ desi.pibriana@mdp.ac.id
}

\begin{abstract}
Abstrak
Perkembangan teknologi dan informasi di jaman sekarang khususnya internet mengalami perkembangan yang sangat pesat. Internet menghubungkan satu orang dengan orang lainnya, menyediakan informasi, sebagai sarana hiburan, maupun sebagai sarana komunikasi. Aplikasi belanja online XYZ merupakan suatu aplikasi dari PT. XYZ yang digunakan untuk melakukan penjualan produk secara online. Setelah survei sederhana kepada 50 orang, diketahui sebanyak 13 orang merupakan pengguna aplikasi belanja online XYZ dan memiliki pendapat yang positif. Untuk mengetahui lebih lanjut apakah pendapat dari 13 orang tersebut dapat mewakili pendapat para pengguna aplikasi belanja online XYZ secara keseluruhan, maka perlu diketahui tingkat penerimaan pengguna terhadap penggunaan aplikasi belanja online tersebut, untuk mengetahui tingkat penerimaan para pengguna, maka digunakanlah metode Technology Acceptance Model (TAM). Dalam melakukan pengumpulan data, penulis menggunakan survey research dengan sampel 365 responden dan untuk analisis data, tools yang digunakan adalah software SPSS untuk menguji validitas dan reliabilitas instrumen variabel dan SmartPLS untuk menguji model. Hasil dari penelitian ini yaitu dari 7 hipotesis yang diajukan,ketujuh hipotesis tersebut dapat diterima dan berpengaruh positif.
\end{abstract}

Kata kunci-Aplikasi Belanja Online XYZ, Technology Acceptance Model (TAM)

\begin{abstract}
The development of technology and information in this day especially the internet experiencing very rapid development. The internet connects one person to another, provide information, as a means of entertainment, and as a means of communication. XYZ Online shopping application is an application from PT. XYZ that is used to sell products online. After a simple survey of 50 people, as many as 13 people are XYZ Online shopping application users and have positive opinions. To find out more about whether the opinions of these 13 people represent the opinions of XYZ Online shopping application users as a whole, then you need to know the level of user acceptance of Online shopping application, to find out the level of user acceptance, the Technology Acceptance Model (TAM) method is used. In conducting data collection, the authors use survey research with a sample of 365 respondents and for data analysis, the tools used are SPSS software to test the validity and reliability of variable instruments and SmartPLS to test the model. The results of this study are of the 7 hypotheses proposed, the seven hypotheses can be accepted and have a positive effect.
\end{abstract}

Keywords - XYZ Online Shopping Application, Technology Acceptance Model (TAM) 


\section{PENDAHULUAN}

$\mathrm{I}^{\prime-1}$ nternet di jaman sekarang ini bukan lagi hal yang asing untuk kita semua. Selain menunjukkan kemajuan di dunia maya, internet juga membuat para masyarakat menjadi sadar akan kehadiran dunia teknologi informasi ditengah kehidupan mereka. Jadi, hal ini bisa dibilang merupakan hal yang baik mengingat banyaknya fungsi dan manfaat internet bagi kehidupan kita semua. Efisiensi kerja merupakan salah satu fungsi yang sangat berguna bagi kita semua [1].

Menurut hasil survei tentang penetrasi dan profil perilaku pengguna internet Indonesia tahun 2018 yang dilaksanakan oleh Asosiasi Penyelenggara Jasa Internet Indonesia (APJII), pengguna internet di Indonesia pada tahun 2018 adalah sebesar 171,17 juta orang dari total populasi yaitu 264,16 juta orang di seluruh Indonesia atau $64,8 \%$ dari seluruh penduduk Indonesia yang meningkat dibandingkan dengan tahun sebelumnya yaitu tahun 2017 yaitu sebesar 143,26 juta orang dari total populasi yaitu 262 juta orang atau 54,68\% dari seluruh penduduk Indonesia. Hal ini menggambarkan bahwa pengguna internet selalu meningkat tiap tahun. Pada tahun 2018, pengguna internet yang terhubung dengan internet melalui smartphone sebesar 93,9\% . Presentase pengguna internet yang melakuan belanja online pada tahun 2018 adalah sebesar $37,7 \%$ [2].

PT. XYZ merupakan salah satu perusahaan di Sumatera Selatan yang sudah menggunakan teknologi dalam salah satu kegiatan operasionalnya yaitu penjualan barang secara online, selain pembeli dapat membeli barang dengan secara langsung datang ke toko, pembeli juga dapat melakukan transaksi pembelian dengan menggunakan aplikasi belanja online XYZ, dengan adanya aplikasi belanja online XYZ maka dapat memudahkan para masyarakat dalam melakukan transaksi pembelian.

Namun setelah survei sederhana yang dilakukan terhadap 50 responden, didapatkan hasil bahwa 58\% dari responden tersebut atau sebanyak 29 responden mengetahui tentang aplikasi belanja online XYZ. Dari 29 responden tersebut, diketahui bahwa $44 \%$ atau sebanyak 13 responden yang hingga saat ini masih menggunakan aplikasi belanja online XYZ, kemudian dilakukan survei lebih lanjut kepada 13 responden tersebut tentang penggunaan aplikasi belanja online XYZ dan didapatkanlah hasil yaitu untuk kemudahan penggunaan aplikasi belanja online $\mathrm{XYZ}$, ada sebanyak 10 responden yang memilih setuju atau sangat setuju, sedangkan untuk kepuasan kinerja aplikasi belanja online XYZ, ada sebanyak 9 responden yang memilih setuju atau sangat setuju. Hingga tanggal 19 September 2019, aplikasi belanja online XYZ sudah mempunyai pengguna sebanyak 4.142 pengguna yang dapat dilihat pada lampiran 1, maka dari itu penulis ingin mengetahui apakah pendapat dari 13 responden tersebut dapat mewakili pendapat pengguna aplikasi belanja online XYZ secara keseluruhan, maka dari itu diperlukannya suatu metode untuk melihat penerimaan dari pengguna terhadap penggunaan aplikasi belanja online XYZ yang dirilis awal tahun 2018 ini.

Untuk mengetahui tingkat penerimaan pengguna dalam menggunakan aplikasi tersebut, salah satu teori yang cukup sering digunakan adalah Technology Acceptance Model (TAM). Technology Acceptance Model (TAM) merupakan suatu model penerimaan sistem teknologi informasi yang akan digunakan oleh pemakai, model ini dikembangkan oleh Davis et al. tahun 1989, Technology Acceptance Model (TAM) mempunyai beberapa konstruk, adapun konstruk konstruk tersebut yaitu persepsi kemudahan penggunaan (Perceived Ease of Use), persepsi kegunaan (Perceived Usefulness), sikap menggunakan teknologi (Attitude Towards Using Technology), sikap untuk menggunakan (Behavioral Intention to Use), dan penggunaan teknologi sesungguhnya (Actual Technology Use), dan [3].

Beberapa penelitian terdahulu yang membahas tentang penerimaan teknologi [4]-[8] dengan menggunakan faktor - faktor kepercayaan, kemudahan, kualitas informasi, kegunaan,

Mayjeksen, et., al [Technology Acceptance Model (TAM) Untuk Menganalisis Penerimaan Pengguna Terhadap Penggunaan Aplikasi Belanja Online XYZ] 
keamanan, kepuasan, niat, resiko, dan kepercayaan pengguna. Sementara pada penelitian ini hanya difokuskan pada kemudahan, kegunaan, niat, dan penggunaan sesungguhnya oleh penggunan sehingga hanya berfokus pada keuntungan dari menggunakan suatu sistem itu sendiri bagi pengguna.

\section{METODE PENELITIAN}

\subsection{Tahapan Penelitian}

Dalam penelitian ini tahapan-tahapan yang akan dilalui adalah sebagai berikut:

1. Identifikasi masalah

2. Studi literatur

3. Menyusun kuesioner

4. Menyebarkan kuesioner

5. Mengolah data

6. Kesimpulan dan saran

Keterangan:

a. Identifikasi masalah, mengidentifikasi masalah yang akan digunakan dalam penelitian ini.

b. Studi literatur, melakukan studi literatur untuk mendapatkan informasi baik yang berkaitan dengan topik penelitian dari berbagai sumber antara lain jurnal, buku maupun artikel.

c. Menyusun kuesioner, melakukan penyusunan pernyataan-pernyataan yang akan digunakan sebagai kuesioner.

d. Menyebarkan kuesioner, melakukan penyebaran kuesioner yang telah disusun sebelumnya. Penyebaran kuesioner dilakukan kepada para pengguna aplikasi belanja online XYZ.

e. Mengolah data, dilakukan dengan menggunakan metode statistik dalam menganalisis data yang berhasil dikumpulkan dari para responden. Pengolahan data meggunakan software SPSS dan SmartPLS.

f. Kesimpulan dan saran, dilakukan setelah melakukan pengujian hipotesis dan mengetahui hubungan antar setiap variabel. Kesimpulan merupakan jawaban dari pertanyaan penelitian yang telah diajukan yang sesuai dengan hasil analisis dan pengujian hipotesis, sedangkan saran merupakan pendapat yang diberikan untuk lebih mengoptimalkan pengelolaan aplikasi belanja online XYZ.

\subsection{Technology Acceptance Model (TAM)}

Model Penerimaan Teknologi atau Technology Acceptance Model (TAM) merupakan suatu model penerimaan sistem teknologi informasi yang akan digunakan pemakai. TAM dikembangkan oleh Davis et al. (1989) berdasarkan model TRA (Theory of Reasoned Action). TAM mempunyai 2 konstruk utama, yaitu persepsi kemudahan penggunaan (perceived ease of use) dan persepsi kegunaan (perceived usefulness). TAM berpendapat bahwa penerimaan individual terhadap sistem teknologi informasi ditentukan oleh 2 konstruk tersebut [3]. Model dari Technology Acceptance Model (TAM) dapat dilihat dalam Gambar 1. 


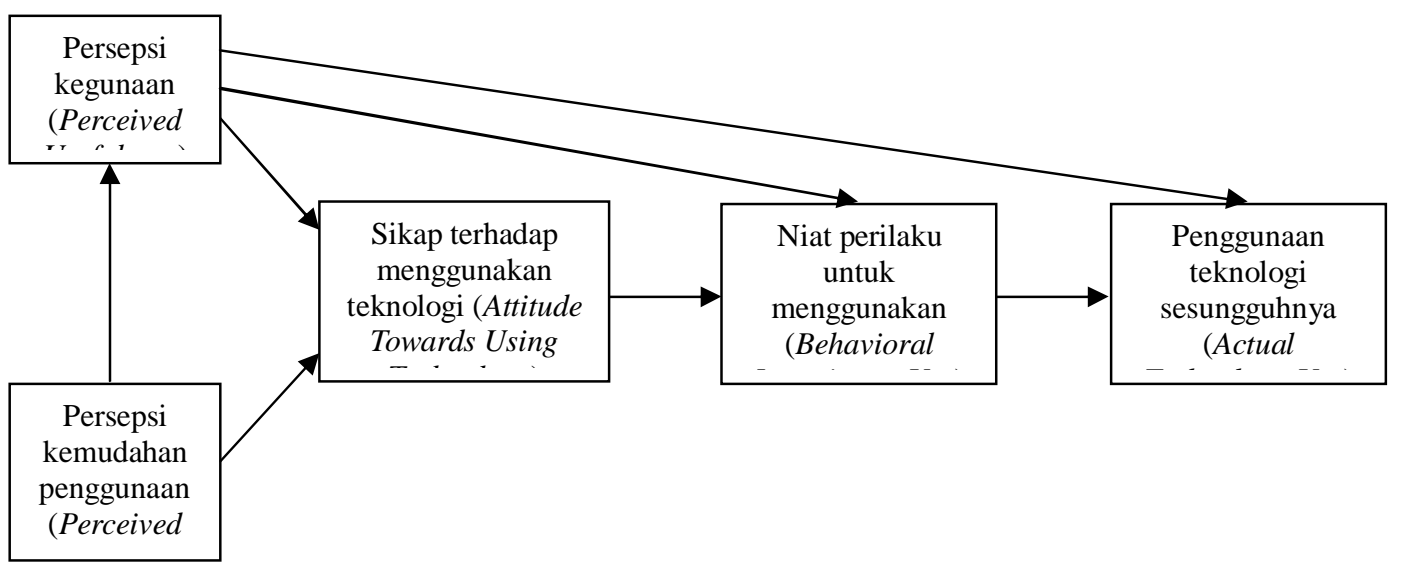

Gambar 1. Model TAM

Adapun konstruk-konstruk TAM yaitu sebagai berikut:

1. Persepsi Kemudahan Penggunaan (Perceived Ease of Use)

Merupakan suatu tingkat kepercayaan seseorang tentang menggunakan suatu teknologi akan bebas dari usaha [3].

2. Persepsi kegunaan (Perceived Usefulness)

Merupakan suatu tingkat kepercayaan seseorang tentang penggunaan suatu teknologi untuk meningkatkan kinerja pekerjaannya [3].

3. Sikap Menggunakan Teknologi (Attitude Towards Using Technology)

Merupakan suatu perasaan seseorang ketika harus melakukan perilaku yang akan ditentukan [3].

4. Niat Perilaku Untuk Menggunakan (Behavioral Intention to Use)

Merupakan suatu keinginan untuk melakukan suatu perilaku tertentu. Seseorang akan melakukan suatu perilaku jika mempunyai keinginan atau niat untuk melakukannya [3].

5. Penggunaan Teknologi Sesungguhnya (Actual technology Use)

Perilaku adalah suatu tindakan yang dilakukan oleh seseorang. Dalam konteks penggunaan sistem teknologi informasi, perilaku adalah penggunaan sesungguhnya teknologi [3].

\subsection{Metode Pengumpulan Data}

Pengumpulan data dalam penelitian ini dengan menggunakan kuesioner dan pertanyaan dalam kuesioner tersebut memiliki pilihan jawaban dengan skala likert. Skala likert digunakan untuk mengukur sikap, pendapat, dan persepsi seseorang atau sekelompok orang tentang fenomena sosial. Di dalam suatu penelitian, fenomena sosial ini telah ditetapkan secara spesifik oleh peneliti, yang selanjutnya disebut dengan variabel penelitian [9].

\section{HASIL DAN PEMBAHASAN}

\subsection{Populasi dan Sampel}

Populasi yang digunakan sebagai sasaran dalam penelitian ini adalah para pengguna aplikasi belanja online XYZ. Per tanggal 19 September 2019, aplikasi belanja online XYZ telah mempunyai pengguna sebanyak 4.142 pengguna.

Teknik sampling yang akan digunakan pada penelitian ini yaitu Simple Random Sampling dimana pengambilan anggota sampel dilakukan secara acak tanpa memperhatikan strata yang ada didalam populasi tersebut [9]

Mayjeksen, et., al [Technology Acceptance Model (TAM) Untuk Menganalisis Penerimaan Pengguna Terhadap Penggunaan Aplikasi Belanja Online XYZ] 


\subsection{Rancangan Kuesioner}

Berdasarkan indikator yang didapatkan dari model penelitian dari yang diajukan, didapatkan sebanyak 23 indikator dimana indikator ini menentukan jumlah pernyataan yang akan dinyatakan dalam kuesioner ini. Adapun indikatornya dapat dilihat pada Tabel 1.

Tabel 1. Rancangan Kuesioner

\begin{tabular}{|l|c|l|c|}
\hline \multicolumn{1}{|c|}{ Variabel } & Nomor Pert. & \multicolumn{1}{|c|}{ Indikator } & Simbol \\
\hline Perceived Ease of Use & 1 & Kemudahan untuk dipelajari/dipahami & PEOU1 \\
& 2 & Kemudahan untuk digunakan & PEOU2 \\
& 3 & Kemudahan untuk mencapai tujuan & PEOU3 \\
& 5 & Kemudahan untuk berinteraksi & PEOU4 \\
\hline Perceived Usefulness & 6 & Fleksibilitas & PEOU5 \\
& 7 & Meningkatkan kinerja & PU1 \\
& 8 & Meningkatkan efisiensi & PU2 \\
& 1 & Menyederhanakan proses kerja & PU3 \\
& 10 & Meningkatkan efektivitas & PU4 \\
Attitude Toward Using & 11 & Sikap penerimaan terhadap sistem & ATUT1 \\
Technology & 12 & Tidak membosankan & ATUT2 \\
& 13 & Menikmati penggunaan & ATUT3 \\
\hline Behavioral Intention & 14 & Perasaan & ATUT4 \\
To Use & 15 & Motivasi tetap menggunakan & BITU1 \\
& 16 & Pilihan utama dalam menggunakan & BITU2 \\
& 17 & Keinginan menggunakan sistem secara & BITU3 \\
& 18 & sering & \\
Actual Technology Use & 19 & Memotivasi ke pengguna lain & Brekuensi penggunaan \\
& 20 & Durasi penggunaan & ATUT1 \\
& 21 & Penggunaan teknologi sesungguhnya & ATUT2 \\
& 22 & Kepuasan pengguna & ATUT4 \\
\hline
\end{tabular}

\subsection{Pengujian Kuesioner}

Setelah kuesioner penelitian telah dibuat dan sebelum disebarkan kepada responden, maka kuesioner diuji validitas dan reliabilitas terlebih dahulu untuk mengukur valid atau tidaknya suatu pernyataan [9].

Pengujian validitas dan reliabilitas dilakukan dengan menggunakan software SPSS 22. Pengujian validitas berkaitan dengan ketrpatan alat ukur yang digunakan, sedangkan pengujian reliabilitas untuk melihat kestabilan data yang digunakan sebagai alat ukur penelitian. Mengukur validitas dilakukan dengan melihat niali korelasi Product Moment Pearson, apabila $\mathrm{r}$ hitung > $r$ tabel maka dinyatakan valid [14]. Sedangkan untuk mengukur reliabilitas dengan menggunakan koefisien alpha yang bias dihitung dengan menggunakan uji statistik Cronbach Alpha dimana suatu konstruk dinyatakan reliabel apabila nilai Cronbach Alpha > 0,7 [14].

\subsection{Analisis Data}

Metode yang digunakan untuk menganalisis data adalah metode statistik dengan menggunakan aplikasi SnartPLS. Data yang telah diperoleh kemudian diolah menggunakan program Microsoft Excel 2007 dan program SPSS 22. Selanjutnya, pengolahan dan analisis data menggunakan aplikasi SmartPLS. 


\subsection{Data Responden}

Populasi dari penelitian ini adalah para pengguna aplikasi belanja online XYZ, dimana dari seluruh populasi pengguna aplikasi belanja online XYZ diambil sampel yang dapat mewakili keseluruhan populasi dengan teknik simple random sampling. Penyebaran kuesioner online dilakukan kepada 365 responden. Adapun demografi responden dari sampel adalah sebagai berikut:

a. Jenis kelamin

Dari responden didapatkan $43,8 \%$ berjenis kelamin laki-laki dan $56,2 \%$ berjenis kelamin perempuan.

b. Umur

Dari keseluruhan responden didapatkan hasil $67,4 \%$ pengguna yang memiliki rentang umur 12-25 tahun, terdapat 28,8\% pengguna rentang umur 26-45 tahun, terdapat 3,6\% dengan rentang umur 46-65 tahun dan tidak ada responden untuk umur diatas 65 tahun.

c. Frekuensi penggunaan dalam 1 bulan

Dari keseluruhan responden didapatkan hasil 66,3\% pengguna yang menggunakan aplikasi belanja online XYZ antara 1-5 kali dalam 1 bulan, terdapat $23 \%$ pengguna yang menggunakan aplikasi belanja online XYZ antara 6-10 kali dalam 1 bulan, dan terdapat $10,7 \%$ pengguna yang menggunakan aplikasi belanja online XYZ lebih dari 10 kali dalam 1 bulan.

\subsection{Model, Variabel, dan Indikator Penelitian}

Model penelitian yang digunakan didalam penelitian ini adalah model penerimaan pengguna atau Technology Acceptance Model (TAM) yang dikembangkan oleh Davis et al. tahun 1989 [3]. Indikator - indikator yang digunakan akan menjadi pernyataan kuesioner yang diajukan kepada responden dapat dilihat pada Tabel 2.

Tabel 2. Variabel, Indikator, dan Pernyataan Dalam Penelitian

\begin{tabular}{|c|c|c|}
\hline Variabel & Indikator & Sumber \\
\hline Perceived Ease of Use & 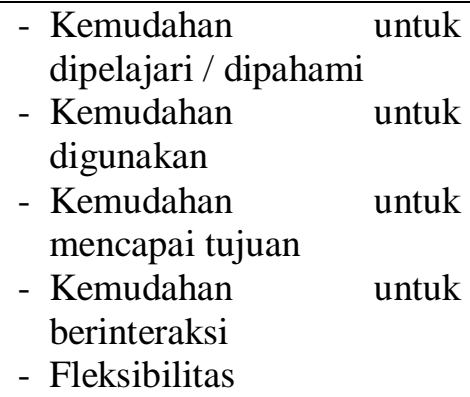 & {$[10]-[12]$} \\
\hline Perceived Usefulness & $\begin{array}{l}\text { - Meningkatkan kinerja } \\
\text { - Menjawab kebutuhan } \\
\text { Informasi } \\
\text { - Meningkatkan efisiensi } \\
\text { - Menyederhanakan proses } \\
\text { kerja } \\
\text { - Meningkatkan efektivitas }\end{array}$ & {$[10],[12],[13]$} \\
\hline Attitude Toward Using Technology & $\begin{array}{l}\text { - Sikap penerimaan } \\
\text { terhadap sistem } \\
\text { - Tidak membosankan } \\
\text { - Menikmati penggunaan }\end{array}$ & {$[10]-[13]$} \\
\hline
\end{tabular}

Mayjeksen, et., al [Technology Acceptance Model (TAM) Untuk Menganalisis Penerimaan Pengguna Terhadap Penggunaan Aplikasi Belanja Online XYZ] 


\begin{tabular}{|c|c|c|}
\hline & - Perasaan & \\
\hline Behavioral Intention To Use & $\begin{array}{l}\text { - } \text { Motivasi tetap } \\
\text { menggunakan } \\
\text { - Pilihan utama dalam } \\
\text { menggunakan } \\
\text { - Keinginan menggunakan } \\
\text { sistem secara sering } \\
\text { - Memotivasi ke pengguna } \\
\text { lain }\end{array}$ & [10]-[13] \\
\hline Actual Technology Use & $\begin{array}{l}\text { - Frekuensi penggunaan } \\
\text { - Durasi penggunaan } \\
\text { - Penggunaan teknologi } \\
\text { sesungguhnya } \\
\text { - Kepuasan pengguna }\end{array}$ & [10], [11], [13] \\
\hline
\end{tabular}

\subsection{Hasil Penelitian}

\subsubsection{Uji Validitas dan Reliabilitas Instrumen}

Uji validitas dilakukan untuk mengetahui kevalidan atas data kuesioner. Uji Validitas dilakukan dengan membandingkan antara $r$ hitung dengan $r$ tabel. Sedangkan nilai dari $r$ hitung dapat dilihat dalam Pearson Correlation pada output program SPSS. Kemudian untuk pengambilan suatu keputusan jika $r$ hitung $>r$ tabel maka variabel penelitian dapat dikatakan valid. Tabel 3 merupakan hasil uji validitas variabel-variabel dalam penelitian ini dan hasil output dari uji validitas instrumen.

Tabel 3. Uji Validitas Instrumen

\begin{tabular}{|c|c|c|c|}
\hline Pernyataan & r hitung & r tabel $\mathbf{( 5 \%} ; \mathbf{N = 3 6 5})$ & Keterangan \\
\hline PEOU1 & 0,784 & 0,102 & Valid \\
\hline PEOU2 & 0,798 & 0,102 & Valid \\
\hline PEOU3 & 0,735 & 0,102 & Valid \\
\hline PEOU4 & 0,669 & 0,102 & Valid \\
\hline PEOU5 & 0,743 & 0,102 & Valid \\
\hline PU1 & 0,747 & 0,102 & Valid \\
\hline PU2 & 0,763 & 0,102 & Valid \\
\hline PU3 & 0,773 & 0,102 & Valid \\
\hline PU4 & 0,723 & 0,102 & Valid \\
\hline PU5 & 0,805 & 0,102 & Valid \\
\hline ATUT1 & 0,764 & 0,102 & Valid \\
\hline ATUT2 & 0,745 & 0,102 & Valid \\
\hline ATUT3 & 0,796 & 0,102 & Valid \\
\hline ATUT4 & 0,770 & 0,102 & Valid \\
\hline BITU1 & 0,819 & 0,102 & Valid \\
\hline BITU2 & 0,835 & 0,102 & Valid \\
\hline BITU3 & 0,855 & 0,102 & Valid \\
\hline BITU4 & 0,816 & 0,102 & Valid \\
\hline ATU1 & 0,809 & 0,102 & Valid \\
\hline ATU2 & 0,814 & 0,102 & Valid \\
\hline
\end{tabular}




\begin{tabular}{|l|l|l|l|}
\hline ATU3 & 0,755 & 0,102 & Valid \\
\hline ATU4 & 0,727 & 0,102 & Valid \\
\hline ATU5 & 0,780 & 0,102 & Valid \\
\hline
\end{tabular}

Setelah dilakukan uji validitas, maka selanjutnya dapat dilakukan uji reliabilitas. Hasil analisis reliabilitas dapat dilihat pada output program SPSS dan ditunjukkan besarnya nilai alpha $(\alpha)$. Pengambilan keputusan reliabilitas jawaban atas suatu variabel ditentukan dengan asumsi apabila nilai alfa cronbach > 0,70 [9] maka butir pertanyaan atas variabel yang diteliti adalah reliabel. Tabel 4 merupakan hasil uji reliabilitas variabel-variabel dalam penelitian ini.

Tabel 4. Uji Reliabilitas Instrumen

\begin{tabular}{|c|c|c|c|}
\hline Variabel & Ralpha & Alpha cronbach & Keterangan \\
\hline PEOU & 0,795 & 0,70 & Reliabel \\
\hline PU & 0,819 & 0,70 & Reliabel \\
\hline ATUT & 0,768 & 0,70 & Reliabel \\
\hline BITU & 0,851 & 0,70 & Reliabel \\
\hline ATU & 0,834 & 0,70 & Reliabel \\
\hline
\end{tabular}

\subsubsection{Uji Model}

Uji Convergent Validity, berfungsi untuk mengetahui validitas setiap hubungan antara indikator dengan konstruk variabel latennya. Di bawah ini hasil pengujian Convergent Validity:

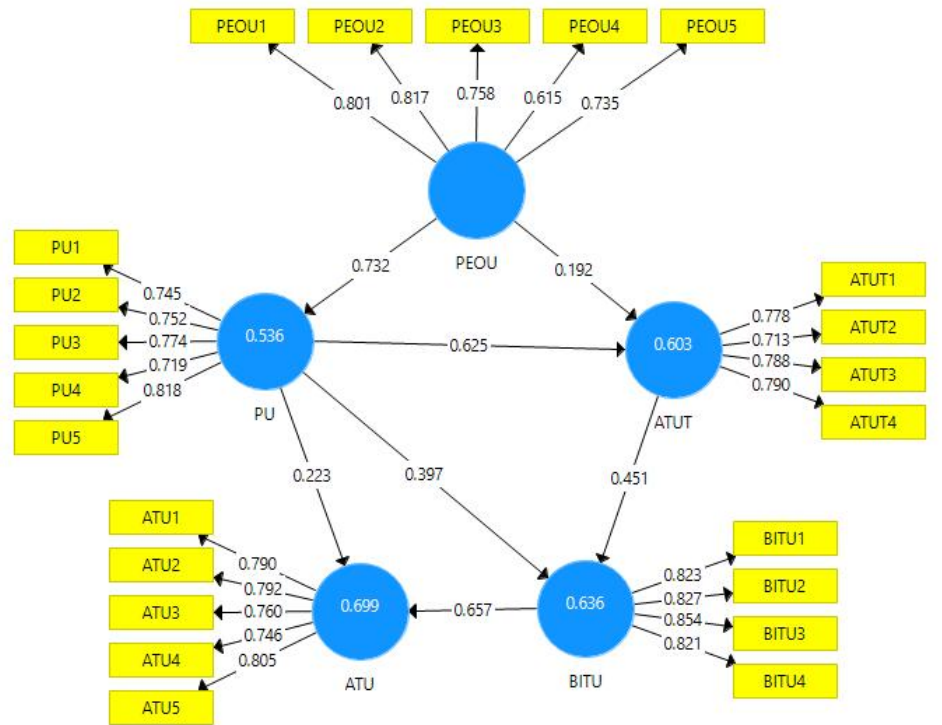

Gambar 2. Uji Convergent Validity

Dari gambar 2 terlihat bahwa indikator loading factor pada semua variabel berada diatas 0,6 [9], hal ini membuktikan bahwa masing-masing konstruk mampu menjelaskan variabel Perceived Ease of Use, Perceived Usefulness, Attitude Towards Using Technology, Behavioral Intention to Use, dan Actual Technology Use.

Uji Discriminant Validity, pada bagian ini akan diuraikan hasil uji discriminant validity. Uji discriminant validity menggunakan nilai cross loading. Suatu indikator dinyatakan memenuhi discriminant validity apabila nilai cross loading indikator pada variabelnya adalah yang terbesar dibandingkan pada variabel lainnya [9]. 
Tabel 5 merupakan hasil dari pengujian Discriminant Validity Latent Variable Correlations:

Tabel 5. Uji Discriminant Validity

\begin{tabular}{|c|c|c|c|c|c|}
\hline \multirow{2}{*}{ Indikator } & \multicolumn{5}{|c|}{ Variabel } \\
\cline { 2 - 6 } & PEOU & PU & ATUT & BITU & ATU \\
\hline PEOU1 & $\mathbf{0 , 8 0 1}$ & 0,558 & 0,533 & 0,496 & 0,490 \\
\hline PEOU2 & $\mathbf{0 , 8 1 7}$ & 0,550 & 0,512 & 0,515 & 0,540 \\
\hline PEOU3 & $\mathbf{0 , 7 5 8}$ & 0,642 & 0,538 & 0,507 & 0,470 \\
\hline PEOU4 & $\mathbf{0 , 6 1 5}$ & 0,457 & 0,418 & 0,432 & 0,410 \\
\hline PEOU5 & $\mathbf{0 , 7 3 5}$ & 0,509 & 0,408 & 0,411 & 0,371 \\
\hline PU1 & 0,668 & $\mathbf{0 , 7 4 5}$ & 0,545 & 0,495 & 0,486 \\
\hline PU2 & 0,495 & $\mathbf{0 , 7 5 2}$ & 0,555 & 0,570 & 0,514 \\
\hline PU3 & 0,549 & $\mathbf{0 , 7 7 4}$ & 0,582 & 0,550 & 0,518 \\
\hline PU4 & 0,494 & $\mathbf{0 , 7 1 9}$ & 0,579 & 0,585 & 0,575 \\
\hline PU5 & 0,583 & $\mathbf{0 , 8 1 8}$ & 0,651 & 0,627 & 0,609 \\
\hline ATUT1 & 0,530 & 0,602 & $\mathbf{0 , 7 7 8}$ & 0,605 & 0,597 \\
\hline ATUT2 & 0,480 & 0,489 & $\mathbf{0 , 7 1 3}$ & 0,480 & 0,495 \\
\hline ATUT3 & 0,475 & 0,559 & $\mathbf{0 , 7 8 8}$ & 0,541 & 0,536 \\
\hline ATUT4 & 0,508 & 0,678 & $\mathbf{0 , 7 9 0}$ & 0,670 & 0,631 \\
\hline BITU1 & 0,544 & 0,631 & 0,628 & $\mathbf{0 , 8 2 3}$ & 0,675 \\
\hline BITU2 & 0,525 & 0,612 & 0,618 & $\mathbf{0 , 8 2 7}$ & 0,666 \\
\hline BITU3 & 0,505 & 0,614 & 0,625 & $\mathbf{0 , 8 5 4}$ & 0,709 \\
\hline BITU4 & 0,535 & 0,613 & 0,640 & $\mathbf{0 , 8 2 1}$ & 0,684 \\
\hline ATU1 & 0,452 & 0,546 & 0,585 & 0,684 & $\mathbf{0 , 7 9 0}$ \\
\hline ATU2 & 0,404 & 0,539 & 0,568 & 0,640 & $\mathbf{0 , 7 9 2}$ \\
\hline ATU3 & 0,434 & 0,537 & 0,542 & 0,602 & $\mathbf{0 , 7 6 0}$ \\
\hline ATU4 & 0,531 & 0,557 & 0,596 & 0,592 & $\mathbf{0 , 7 4 6}$ \\
\hline ATU5 & 0,566 & 0,589 & 0,595 & 0,677 & $\mathbf{0 , 8 0 5}$ \\
\hline
\end{tabular}

Sementara itu, hasil Uji Average Varian Extraced (AVE) pada penelitian ini dapat dilihat pada Tabel 6 .

Tabel 6. Uji AVE

\begin{tabular}{|l|l|}
\hline & AVE \\
\hline PEOU & 0,561 \\
\hline PU & 0,581 \\
\hline ATUT & 0,590 \\
\hline BITU & 0,691 \\
\hline ATU & 0,606 \\
\hline
\end{tabular}

Dari hasil UJI AVE pada Tabel 6 dapat dilihat bahwa indikator PEOU, PU, ATUT, BITU, dan ATU memiliki nilai > 0,50 artinya memenuhi kriteria penilaian [9].

Uji Composite Reliability dan Cronbach Alpha, Untuk memastikan bahwa tidak terdapat permasalahan terkait pengukuran maka langkah terakhir dalam Outer Model adalah melakukan uji unidimensionalitas dengan menggunakan indikator Composite Reliability dan Cronbach Alpha. Untuk nilai yang diharapkan pada Composite Reliability dan Cronbach Alpha diatas 0,70 [9]. 
Uji $\boldsymbol{R}^{2}$ Untuk Variabel Laten Endogen, Untuk uji $R^{2}$ variabel laten endogen mengidentifikasikan bahwa hasil $R^{2}>0,67$ (Baik), 0,33 (Moderat) dan 0,19 (Lemah) untuk variabel laten endogen [9]. Hasil Uji $R^{2}$ dapat dilihat pada Tabel 7.

Tabel 7. Uji $\boldsymbol{R}^{2}$ Untuk Variabel Laten Endogen

\begin{tabular}{|c|c|c|c|}
\hline & $\boldsymbol{R}^{\mathbf{2}}$ & PERSENTASE & KETERANGAN \\
\hline ATU & 0,699 & $69,9 \%$ & BAIK \\
\hline ATUT & 0,603 & $60,3 \%$ & MODERAT \\
\hline BITU & 0,636 & $63,6 \%$ & MODERAT \\
\hline PU & 0,536 & $53,6 \%$ & MODERAT \\
\hline
\end{tabular}

Dalam penelitian ini, terdapat lima variabel, yaitu Perceived Ease of Use (PEOU), Perceived Usefulness (PU), Attitude Towards Using Technology (ATUT), Behavioral Intention to Use (BITU), dan Actual Technology Use (ATU). Suatu variabel dikatakan berpengaruh signifikan terhadap variabel lainnya ketika t-statistik > t-tabel [9]. Untuk menentukan nilai ttabel dapat diketahui dengan cara melihat dari t-tabel. Dari jumlah sampel yang diuji lalu menentukan nilai alpha yang digunakan pada penelitian. Pada penelitian ini menggunakan nilai alpha 0,05 dan jumlah sampel sebanyak 365 dan menentukan nilai $d . f$ dengan rumus (n-1) jadi d.f yang diambil yaitu 364. Jadi t-tabel yang digunakan pada penelitian ini 1,649. Hasil Uji terhadap Path Coefficients pada penelitian ini dapat dilihat pada Tabel 8.

Tabel 8. Hasil Path Coefficients

\begin{tabular}{|l|c|c|l|}
\hline & Sampel Asli & t-statistik & Keterangan \\
\hline PEOU $\rightarrow$ PU & 0,732 & 25,504 & Berpengaruh \\
\hline $\mathrm{PU} \rightarrow$ ATUT & 0,625 & 13,299 & Berpengaruh \\
\hline PEOU $\rightarrow$ ATUT & 0,192 & 3,867 & Berpengaruh \\
\hline PU $\rightarrow$ BITU & 0,397 & 7,863 & Berpengaruh \\
\hline PU $\rightarrow$ ATU & 0,223 & 4,655 & Berpengaruh \\
\hline ATUT $\rightarrow$ BITU & 0,451 & 8,994 & Berpengaruh \\
\hline BITU $\rightarrow$ ATU & 0,657 & 15,553 & Berpengaruh \\
\hline
\end{tabular}

\subsubsection{Kesimpulan Pengujian Hipotesis}

Setelah melalui beberapa tahapan analisis data menggunakan aplikasi SPSS 22 dan SmartPLS, hasil akhir pengolahan data harus diinterpretasikan untuk membuktikan hipotesis penelitian yang telah diajukan. Kesimpulan dari setiap hipotesis sebagai hasil dari analisis hubungan antar konstruk pada model penelitian adalah semua 7 hipotesis yang diajukan dapat diterima dikarenakan semua 7 hipotesis terbukti berpengaruh positif.

\section{KESIMPULAN DAN SARAN}

Berdasarkan hasil analisis data yang sudah dilakukan, dapat disimpulkan bahwa:

1) Persepsi kemudahan penggunaan aplikasi belanja online XYZ berpengaruh positif terhadap persepsi kegunaan penggunaan dengan mempunyai nilai t-statistik 25,504.

Sehingga kemudahan menggunakan aplikasi belanja online XYZ mempunyai pengaruh signifikan terhadap penggunaan aplikasi belanja online XYZ 
2) Persepsi kegunaan penggunaan aplikasi belanja online $X Y Z$ berpengaruh positif terhadap sikap penggunaan aplikasi belanja online XYZ dengan mempunyai nilai t-statistik 13,299. Sehingga manfaat menggunakan aplikasi belanja online XYZ mempunyai pengaruh signifikan terhadap sikap dalam menggunakan aplikasi belanja online XYZ.

3) Persepsi kemudahan penggunaan aplikasi belanja online XYZ berpengaruh positif terhadap sikap penggunaan aplikasi belanja online XYZ dengan mempunyai nilai t-statistik 3,867.

Sehingga kemudahan menggunakan aplikasi belanja online XYZ mempunyai pengaruh signifikan terhadap sikap dalam menggunakan aplikasi belanja online XYZ.

4) Persepsi kegunaan penggunaan aplikasi belanja online $X Y Z$ berpengaruh positif terhadap perilaku keinginan untuk dengan mempunyai nilai t-statistik 7,863.

Sehingga manfaat menggunakan aplikasi belanja online XYZ mempunyai pengaruh signifikan terhadap niat untuk menggunakan aplikasi belanja online XYZ.

5) Persepsi kegunaan penggunaan aplikasi belanja online XYZ berpengaruh positif terhadap pemakaian teknologi sesungguhnya dengan mempunyai nilai t-statistik 4,655.

Sehingga manfaat menggunakan aplikasi belanja online XYZ mempunyai pengaruh signifikan terhadap penggunaan sesungguhnya aplikasi belanja online XYZ .

6) Sikap terhadap penggunaan aplikasi belanja online XYZ berpengaruh positif terhadap perilaku keinginan untuk dengan mempunya inilai t-statistik 8,994.

Sehingga sikap menggunakan aplikasi belanja online XYZ mempunyai pengaruh signifikan terhadap niat untuk menggunakan aplikasi belanja online XYZ.

7) Perilaku keinginan untuk menggunakan berpengaruh positif terhadap pemakaian teknologi sesungguhnya dengan mempunyai nilai t-statistik 15,553.

Sehingga keinginan untuk menggunakan aplikasi belanja online XYZ mempunyai pengaruh signifikan terhadap penggunaan sesungguhnya aplikasi belanja online XYZ.

\section{SARAN}

Saran yang diberikan kepada berbagai pihak terkait dengan hasil penelitian ini adalah sebagai berikut:

1) Penelitian ini dapat memberikan informasi kepada pihak PT. XYZ untuk memaksimalkan fitur aplikasi belanja online XYZ agar dapat diterima oleh para pengguna.

2) PT. XYZ sebagai pemilik dari aplikasi belanja online $X Y Z$ dapat terus mempertahankan dan meningkatkan kemudahan penggunaan aplikasi belanja online XYZ agar dapat lebih mudah digunakan oleh para pengguna sehingga dapat lebih meningkatkan manfaat menggunakan aplikasi belanja online XYZ sesuai dengan hasil dari penelitian ini dimana kemudahan pengggunaan mempunyai pengaruh yang paling besar kepada manfaat penggunaan, dan dari hasil penelitian ini juga diketahui bahwa kemudahan penggunaan aplikasi belanja online XYZ mempunyai pengaruh yang lebih kecil terhadap sikap menggunakan aplikasi belanja online XYZ dibandingkan dengan manfaat penggunaan aplikasi belanja online XYZ.

3) Hasil dari penelitian ini diharapkan dapat memberikan masukkan dan menjadi acuan bagi penelitian selanjutnya untuk melakukan penelitian dengan menggunakan indikator yang lebih terperinci pada tiap variabel untuk hasil yang lebih baik lagi.

\section{UCAPAN TERIMA KASIH}

Terima kasih kepada pihak PT.XYZ untuk dukungan dalam pelaksanaan kegiatan penelitian ini.

Mayjeksen, et., al [Technology Acceptance Model (TAM) Untuk Menganalisis Penerimaan Pengguna Terhadap Penggunaan Aplikasi Belanja Online XYZ] 


\section{DAFTAR PUSTAKA}

[1] Madcoms. 2008, Panduan Menggunakan Internet untuk Pemula, Andi Offset, Yogyakarta.

[2] APJII. 2019, "Penetrasi \& Profil Perilaku Pengguna Internet Indonesia Tahun 2018," Apjii, p. 51.

[3] H. Jogiyanto. 2007, Sistem Informasi Keprilakuan, Andi Offset. Yogyakarta.

[4] B. Adityo. 2011, "Analisis Pengaruh Kepercayaan, Kemudahan dan Kualitas Informasi Terhadap Keputusan Pembelian Secara Online di Situs Kaskus,” Vol. 53, No. 9, pp. 1689-1699.

[5] O. S. Herdiyanto and D. S. Hidayahtullah. 2018, "Analisis Niat Pengguna Tokopedia Dengan Pendekatan Technology Acceptance Model (Studi Kasus Mahasiswa Fakultas Ekonomi dan Bisnis Telkom University) Analysis Usage Intention of Tokopedia Using Technology Accaptance Model (Study on Students of Economic)," Vol. 5, No. 3, pp. 3020-3034.

[6] J. Ilmiah, I. Komputa, and E. Volume, "Analisis Penerimaan Pengguna pada Website Lazada Dengan Menggunakan Technology Acceptance Model ( TAM ) Jurnal Ilmiah Komputer dan Informatika ( KOMPUTA )."

[7] N. Fiyah, N. A. Mayangky, S. Hadianti, and D. Riana. 2019, "Analisis Technology Acceptance Model pada Aplikasi Platform Perdagangan Elektronik di Kalangan Mahasiswa," J. Tek. Inform., Vol. 12, No. 1, pp. 59-68.

[8] Dimas Ernomo Putra, E. S. Astuti, and Riyadi. 2015, "Pengaruh Kemudahan Terhadap Kemanfaatan, Minat dan Penggunaan E-Commerce," J. Adm. Bisnis, Vol. 21, No. 2, pp. $1-8$.

[9] Wiyono. 2011, Merancang Penelitian Bisnis Dengan Alat Analisis SPSS \& SmartPLS. Yogyakarta.

[10] A. Hanggono. 2015. "Analisis Atas Praktek Tam (Technology Acceptance Model) Dalam Mendukung Bisnis Online Dengan Memanfaatkan Jejaring Sosial Instagram," J. Adm. Bisnis, Vol. 26, No. 1, pp. 1-9.

[11] F. S. Rahayu, D. Budiyanto, and D. Palyama. 2017, “Analisis Penerimaan E-Learning Menggunakan Technology Acceptance Model (TAM) (Studi Kasus: Universitas Atma Jaya Yogyakarta)," J. Terap. Teknol. Inf., Vol. 1, No. 2, pp. 87-98.

[12] D. R. Tobergte and S. Curtis. 2013, “Analisis Faktor-Faktor Penerimaan Penggunaan Quiooerschool.com Dengan Menggunakan Pendekatan Technology Acceptance Model (TAM), " J. Chem. Inf. Model., Vol. 53, No. 9, pp. 1689-1699. 
[13] A. Wibowo and U. B. Luhur. 2017, "Kajian Tentang Perilaku Pengguna Sistem Informasi Dengan Pendekatan Technology Acceptance Model ( TAM )," Konf. Nas. Sist. Inf., No. Universitas Budi Luhur, Jakarta, pp. 1-8.

[14] Priyatno. 2014, SPSS 22: Pengolah Data Terpraktis. Yogyakarta. 